\title{
REFERENCING INTERNATIONAL HUMAN RIGHTS LAW IN INDONESIAN CONSTITUTIONAL ADJUDICATION
}

\author{
Bisariyadi* \\ The Constitutional Court of the Republic of Indonesia, Indonesia
}

\begin{abstract}
The power of the Indonesian Constitutional Court to review laws is a constitutional adjudication process. It is a forum to resolve constitutional issues where a citizen can challenge Law that has injured his rights. The Court's reasoning provides audiences with the debates for its deliberation. Audiences may find reference to the international human rights law. It is an interesting practice. However, there is no studies yet about the information on the statistic of the Court made reference to international human rights law. As such, this study aims to identify reference to international human rights law in the Court's decision on judicial review cases from 2003 to 2016. Additionally, this study also aims to answer the question of what underlies the Court to made reference to international human rights law. As many studies show, the objective of Constitutional Court's references to the international human rights law is to strengthen constitutional rights protection. Nonetheless, the Court did not pay any interests to the global agenda of transnational constitutionalism or a convergence of rights and legal pluralism. The article is divided into 5 (five) sections, commencing with the introduction. The second part discusses the status of international human rights law in Indonesia. As the third presents information on Court's decision which cited international human rights law. Then, the fourth presents typical function of the decision that made reference to international human rights law. It concluded that the practice of referring to international law demonstrates the open attitude of Indonesian constitutional justices to the universal nature of fundamental rights.
\end{abstract}

Keywords: Constitution, Constitutional Adjudication, Constitutional Court, International Human Rights Law, Judicial Review.

* Bisariyadi is a researcher at the Center for Research and Case Study and the Library Management at The Constitutional Court of the Republic of Indonesia.

The author would like to thank Michael Vagias and Anbar Jayadi for helpful comments and suggestions on an earlier version of this article. 


\section{INTRODUCTION}

The interest of legal researchers and academics of political science for court decisions that make references to foreign and international law is immense. Theoretical approaches and comparative studies on the topic have been written in research papers as well as books. Scholars identify different concepts and coin different terms for the different approaches, such as transplants, ${ }^{1}$ borrowing, ${ }^{2}$ reception, ${ }^{3}$ and migration. ${ }^{4}$

In practice, the approach of judicial institutions mandated to carry out constitutional adjudication towards foreign law varies considerably. Some show resistance, whereas others evidence an open attitude to embrace a comparative approach. An illustration may provide a glimpse of the divergent use of comparative approaches by national courts. The German Federal Constitutional Court rarely has recourse to a comparative approach. During the period 19912005, the Court issued three decisions that take a comparative approach in its reasoning. ${ }^{5}$ Similarly, the High Court of Japan made no legal comparison in its decisions, between 1990 and 2008. However, there are 11 dissenting opinions that make references to foreign or international law in the same time frame. ${ }^{6}$ In Taiwan, the High Court also rarely refers to the praxes of other countries and international legal instruments. There are only four decisions that use the legal comparison in the Courts decisions between 1949 and $2008 .^{7}$

On the other hand, the High Court of Australia regularly employed a comparative legal approach between 1998 and 2008. ${ }^{8} \mathrm{~A}$ high number of references

\footnotetext{
Edward M. Wise, "The Transplant of Legal Patterns", The American Journal of Comparative Law 38, (1990): 1-22. Berry Friedman and Cheryl Saunders, "Introduction to the Symposium on Constitutional Borrowing," International Journal of Constitutional Law 1, No. 2 (2003): 177-180; Wiktor Osiatynski, "Paradoxes of Constitutional Borrowing", International Journal of Constitutional Law 1, No.2, (2003): 244-268.

3 Wolfgang Wiegand, "Reception of American Law in Europe," American Journal of Comparative Law 39, no. .2, (1991): 229-248.

4 Sujit Choudhry, "Migration as a New Metaphor in Comparative Constitutional Law," in The Migration of Constitutional Idea, ed. Sujit Choudhry (Cambridge: Cambridge University Press, 2006), 1-37.

Basil Markesinis and Jorg Fedtke, Judicial Recourse to Foreign Law (New York: Routledge-Cavendish, 2006), 77.

Akiko Ejima, "Enigmatic Attitude of the Supreme Court of Japan towards Foreign Precedents - Refusal at the Front Door and Admission at the Back Door," Meiji Law Journal 16, (2009): 28.

7 Wen-Chen Chang and Jiunn-Rong Yeh, "The Use of Foreign Precedents in the Constitutional Court in Taiwan" (Preliminary Report for the IACL Research Group, 2008).

8 Cheryl Saunders, "Judicial Engagement with Comparative Law," in Comparative Constitutional Law, ed. Tom Ginsburg and Rosalind Dixon (Chetenham: Edward Elgar, 2011): 573.
} 
to foreign sources also appear in the jurisprudence of the Constitutional Court of South Africa. The Court used a comparative approach on more than 300 decisions since $1994 .{ }^{9}$ One reason behind the high statistical figure is that Art. 39 (1) b and c of the South African Constitution stipulate that in interpreting the bill of rights, the courts should consider international legal instruments and may refer to the practice of law in other countries.

The definition of comparative law includes a reference to the instruments of international law. The practice of refering to international law is triggered by the development of global constitutionalism that which makes evident the connection between constitutional protection to human right in domestic law with the protection in international human rights law. The rapid development of this discussion is based on the idea of unification of universal values. Scholars that endorse the idea coined the terms "internationalization of constitutional laws" and conversely "constitutionalization of international laws". ${ }^{10}$

However, interest on the topic is not followed by research projects in Asian countries. Literature that provides information on the topic is lacking, especially in Indonesia. A study by Diane Zhang examined the Constitutional Court rulings from 2003 to 2008 . She identifies 813 references to foreign legal excerpts from 62 Court's decisions." foreign law in the Court's decisions. In her research, Zhang does not focus only on instruments of international law, but also includes foreign laws as well as excerpts from the relevant scientific literature. Her research includes the Court reference to Joseph Stiglitz, a Nobel prize winner whose book "Globalization and its Discontent" is quoted in one of the decisions. ${ }^{12}$

\footnotetext{
Ursula Bentele, "Mining for Gold: The Constitutional Court of South Africa's Experience with Comparative Constitutional Law," Georgia Journal of International and Comparative Law 37, no. 2 (2009): 219.

10 Herman Schwartz, "The Internationalization of Constitutional Law," Human Rights Brief 10, no. 2 (2003); Vicki C. Jackson, Constitutional Engagement In A Transnational Era (Oxford University Press, 2010); Nicholas Tsagourias, Transnational Constitutionalism: International And European Models, (Cambridge: Cambridge University Press, 2007); Jiunn-Rong Yeh and Wen-Chen Chang, "The Emergence of Transnational Constitutionalism: Its Features, Challenges and Solutions," Pennsylvania State International Law Review 27, no. 1, (2008): 89.

11 Diane Zhang, "The Use and Misuse of Foreign Materials by the Indonesian Constitutional Court: A Study of Constitutional Court Decisions 2003-2008" (Master Thesis, The University of Melbourne, 2010).

12 Decision 001-021-022/PUU-1/2003, 331
} 
Beyond Zhang's research, the study of comparative law and the influence of international law in the Constitutional Court's decisions is still left unexplored. To fill the gap in the Indonesian academic literature on the use of foreign sources in the decisions of the Constitutional Court, this study will identify the court's practice on the use of a comparative approach with focus on reference to the international human rights law.

This paper will discuss the Court's jurisprudence on judicial review cases from 2003 to 2016. In addition to identifying decisions, it also examines the reasons underlying the use of international human rights law by the Court. Accordingly, this article will be divided into five sections beginning with the introduction. The second section will discuss the status and enforceability of international law in the Indonesian legislation. The third section will present data on judicial review decisions containing references to international law. The fourth section discusses the reasons and the function of international human rights law references in judicial review cases before the Indonesian Constitutional Court. The last section is the conclusion.

\section{THE STATUS OF INTERNATIONAL LAW IN THE INDONESIAN LEGAL ORDER}

Indonesia adopted civil law tradition as it is inherited from the Dutch in the colonial era. In relation to the adoption of international law into domestic law, civil law tradition tends to use the monist approach, ${ }^{13}$ where international law automatically forms part of domestic law. ${ }^{14}$ This apply in practice of the Netherlands, ${ }^{15}$ Taiwan, ${ }^{16}$ and South Korea. ${ }^{17}$ However, Indonesia's position, in this case, is still in debate. ${ }^{18}$

${ }_{13}$ Daniel Lovric, "A Constitution Friendly to International Law: Germany and Its Volkerrechtsfreundlichkeit," Australian Year Book of International Law 25, (2006): 75.

${ }_{14}$ J.G. Starke, Pengantar Hukum Internasional [The Introduction of International Law], trans. Bambang Djajaatmadja (Jakarta: Sinar Grafika, 2008), 96-103.

15 Gerhard van der Schyff and Anne Meuwese, "Dutch Constitutional Law in a Globalising World," Utrecht Law Review 9, no. 2 (2013): 1.

16 Wen-Chen Chang, "An Isolated Nation with Global-minded Citizens: Bottom-up Transnational Constitutionalism in Taiwan", National Taiwan Law Review 4, No.3 (2009): 209.

17 Suk Tae Lee, "South Korea: Implementation and Application of Human Rights Covenants," Michigan Journal of International Law 14, (1993): 728.

18 Simon Butt, "The Position of International Law Within the Indonesian Legal System" Emory International Law Review, 28, no. 1, (2014): 5 
In Indonesia, international law needs to be ratified in order to be enforced. Yet, the form of legislation is still in question. ${ }^{19}$ The trigger to this debate is the ambiguity in the constitutional text. Article 11 of the 1945 Constitution provides that "the President with the consent of the House of Representatives declares war, makes peace and agreements with other countries". The amendment of the 1945 Constitution, in 1999-2002, added a more detail provision to the requirement of international treaty-making arrangements. Article 11 (2) of the 1945 Constitution reads,

"The President in making other international treaties which have a broad and fundamental effect on the lives of the people in association with the financial burden of the state, and / or requiring the amendment to the Law shall be subject to the approval of the House of Representatives."

Nonetheless, the additional provision does not mean much in giving a clear understanding to the Indonesian approach to international law.

The government has issued different arrangement policies to enforce international law as a translation to Article 11 of the 1945 Constitution. The policies are divided into three legal regimes, (1) Policy in the period of 1945-1960 with three different constitutions: the 1945 Constitution, the 1949 Constitution of Republic of Federal Indonesia (Republik Indonesia Serikat) and the Temporary Constitution of 1950 (Undang-Undang Dasar Sementara Tahun 1950); (2) Policy in the period of 1960-200o based on Presidential Letter No. 2826/1960; and (3) Period of 2000 - current pursuant to the enactment of Law No. 24 of 2000 on International Agreements. ${ }^{20}$

The phrase "subject to approval of the House of Representatives", as provided in Article 11(2) of the Indonesian constitution added the complexity of the adoption of international law in domestic law. The provision stipulates

19 Mochtar Kusumaatmadja and Etty R Agoes, Pengantar Hukum Internasional, (Bandung: Penerbit Alumni, 2003), 88-94; M. Fajrul Falaakh in Expert Witness as delivered at the Constitutional Court Session as cited in Decision 33/PUU-IX/2011, 121.

20 Damos Dumoli Agusman, "Dasar Konstitusional Perjanjian Internasional Mengais Latar Belakang dan Dinamika Pasal 11 UUD 1945 [Constitutional Foundation on International Treaty: Taking the Background and the Dynamic of article 1 of the 1945 Constitution of the Republic of Indonesia]," Opinio Juris 4 (Januari-April 2012): 1; Damos Dumali Agusman, "The Dynamic Development of Indonesia's Attitude Toward International Law," Indonesian Journal of International Law 13, No. 1 (October 2015): 5-15. 
that government's policy in ratifying international treaties must be manifested in the Statute (Undang-Undang) simply because the type of legislation issued in the joint approval of the President and the House of Representatives is the law.

The Constitutional Court, in the review of constitutionality of Law No. 38 of 2008 on ratification of Association of South East Asian Nations (ASEAN) Charter, gave an interpretation to Article 11 of the 1945 Constitution. The Court concluded that Law, as a legislative product to ratified international treaties must be take a second consideration..$^{21}$ The Court argued that the obligations imposed to the state parties by international treaties are not born when the treaty is ratified as a law.22 Based on the principle of pacta sunt servanda, the obligations of the parties are born when the state as a party have declared their consent to be bound. The practice is also affirmed in the Vienna Convention on the Law of Treaties. ${ }^{23}$ The enactment of international agreements in the Law serves as a form of internal mechanism of ratification. In Indonesia, the mechanism is provided under Article 11 of the 1945 Constitution. In view of the Court,

"Article 11 of the 1945 Constitution does not mention that the form of ratification to international treaty is in a law, but states that the President with the approval of Parliament makes an international agreement. If this mechanism is associated with the enactment of the Law, it is a legal product of the President and the House of Representatives. However, this does not mean that every legal product issued by the President and the House of Representatives is in a Law."

The policy to ratify international treaties by the issuance of the Law is a common practice. ${ }^{24}$ International treaties ratification means that the treaties come into force in the domestic legal order by the issuance of the law.

In Indonesian practice, however, there is international law on human rights that was adopted not by the issuance of the law. The Convention on the Rights of the Child was ratified by Presidential Decree (table 1).

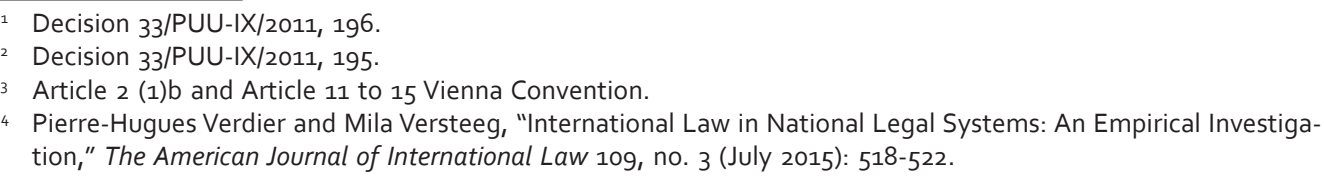


Table 1.

Ratification of Major International Human Rights Law Treaties by Indonesia

No. Human Rights Instruments

(Ratification in) Indonesian Laws

1. Convention on the Elimination of Law No. 7 of 1984 All Forms of Discrimination against Women

2. Convention on the Rights of the Child Presidential Decree No. 36 of 1990

a. Optional Protocol to the Convention Law No. 9 of 2012 on the Rights of the Child on the involvement of children in armed conflict

b. Optional Protocol to the Convention Law No. 10 of 2012 on the Rights of the Child on the sale of children, child prostitution and child pornography

3. Convention against Torture and Other Law No. 5 of 1998 Cruel, Inhuman or Degrading Treatment or Punishment

4. International Convention on the Law No. 29 of 1999 Elimination of All Forms of Racial Discrimination

5. International Covenant on Economic, Law No. 11 of 2005 Social and Cultural Rights

6. International Covenant on Civil and Law No. 12 of 2005 Political Rights

7. Convention on the Rights of Persons Law No. 19 of 2011 with Disabilities

8. International Convention on the Law No. 6 of 2012 Protection of the Rights of All Migrant Workers and Members of their Families 


\section{REFERENCING INTERNATIONAL HUMAN RIGHTS LAW}

In judicial review cases, individual may appear as plaintiffs before the Constitutional Court in order to challenge the constitutionality of domestic laws. The Law requires that person or entities must be able to prove that their constitutional rights have been impaired by the enactment of the law under review in order to admissable as parties. ${ }^{25}$

The catalogue of the bill of rights in the constitution is intertwined with human rights. ${ }^{26}$ One distinction lies in the legal instruments through which the rights are governed. The human rights as provided in the Constitution are referred to as constitutional rights. In terms of domestic law, constitutional rights sit at the top since the constitution is the supreme law of the land. ${ }^{27}$ The question lies in where are the human rights as provided in international law sits in domestic law? Do human rights as provided in international law have a higher hierarchy than constitutional rights? If the human rights as governed in international law are not in the bill of rights catalogue in the Constitution, does the court has the power to consider them as constitutionally protected rights?

In theory, these questions have served as a framework of reference for the research of legal academics and political scholars. In practice, the approach taken by countries varies. South Africa is the example of the state with open attitude towards the interpretation to the rights in international legal instruments. Article 39 (1) b of the Constitution of South Africa states "(w)hen interpreting the Bill of Rights, a court, tribunal or forum: ..must consider international law". Then, where does the Indonesian Constitutional Court stand?

Since 2003, the Court has decided more than one thousand cases. This study limits the scope of the decision between 2003 and 2016. It aims to give a complete picture of the decisions issued during the period. The study does not include cases registered in 2017 as during the research the cases are still being examine before the Court. It also limits the scope of the decision

\footnotetext{
25 Art. 51 (2) Law No. 24 of 2003 on Constitutional Court (as amend Law No. 8 of 2011).

26 Gerald L. Neuman, "Human Rights and Constitutional Rights: Harmony and Dissonance", Stanford Law Review 55, no. 5 (May 2003): 1863-1900.

27 Art. 7 (1) Law No 12 of 2011 on Regulation Drafting.
} 
to decisions where the Court decided to "reject" and "grant" the petition. Therefore, inadmissible decisions are not included in the study. This is because the Court's consideration in inadmissibility decisions only discusses as far as the administrative and admissibility issues of the case and does not touch the merits on the constitutionality of the Law.

The study included international human rights instruments of both nonbinding and binding nature. The non-binding nature of international human rights law covers Universal Declaration on Human Rights (UDHR), the Basic Principles on the Independence of the Judiciary, and The Cairo Declaration on Human Rights in Islam. Under binding international human rights law the study incorporates the International Covenant on Civil and Political Rights (ICCPR), the International Covenant on Economic, Social and Cultural Rights (ICESCR), and the International Convention on the Elimination of All Forms of Racial Discrimination (CERD).

Within this limitation, the study identifies 597 decisions. The study finds that there are 52 rulings ( $8.7 \%)$ in which the majority opinion provided citations to international human rights law as a reference. On average, the Constitutional Court's decisions that provide reference to international human rights law per year are 3.7. Table 2 describes in detail the decisions of the Constitutional Court which refer to international law compared to the number of decisions that become the basis of analysis data each year.

Table 2.

Number of Constitutional Court decisions containing international legal references per year

\begin{tabular}{|c|c|c|c|c|c|c|c|c|c|c|c|c|c|c|}
\hline Year & $\begin{array}{l}\text { No } \\
\text { O }\end{array}$ & 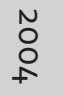 & $\begin{array}{l}\text { No } \\
\text { O } \\
\text { ㄴ }\end{array}$ & $\begin{array}{l}\text { N } \\
\text { O } \\
\text { ă }\end{array}$ & N & $\begin{array}{l}\text { N } \\
\text { O } \\
\infty\end{array}$ & $\begin{array}{l}\text { N } \\
\text { O } \\
0\end{array}$ & $\stackrel{N}{\circ}$ & $\begin{array}{l}\text { No } \\
\text { 岁 }\end{array}$ & $\stackrel{N}{\stackrel{N}{N}}$ & 金 & 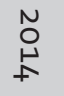 & $\begin{array}{l}\text { N } \\
\text { 嵌 }\end{array}$ & 只 \\
\hline $\begin{array}{l}\text { "Granted" and } \\
\text { "Rejected" } \\
\text { Holdings }\end{array}$ & 15 & 13 & 16 & 16 & 18 & 23 & 52 & 51 & 50 & 78 & 70 & 64 & 76 & 55 \\
\hline $\begin{array}{l}\text { Reference to Intl } \\
\text { Law in Decision }\end{array}$ & 3 & 3 & 1 & 2 & 2 & 4 & 5 & 6 & 1 & 2 & 4 & 5 & 6 & 8 \\
\hline
\end{tabular}

Source: author 
The international human rights law instruments that serve as reference more frequently are the ICCPR, UDHR and ICESCR (Table 3). The ICCPR is widely used as a reference especially in relation to the interpretation on the definition of "discrimination".

Discrimination became a central issue in a number of cases before the Constitutional Court of Indonesia. The plaintiff mostly argue that a certain requirement to hold public office as stipulated in the law has a different treatment. The difference, according to the plaintiff, is a form of prohibited discrimination. For example, in the determination of number of seats for members of parliament (Decision No. 130/PUU-VII/2009) and policies that differentiated the requirement of incumbent to run for second terms with the incumbent to run for public office in the different region (Decision No. 55/ PUU-XIV/2016). Those policies are challenged on the ground that they injured the plaintiff's constitutional rights, especially the right to equal treatment and prohibition of discriminatory acts. The Court explained that discrimination must be interpreted in accordance with Article 2 of the ICCPR whereby the protection and recognition of the rights of every person shall be conducted "...without distinction of any kind, such as race, colour, sex, language, religion, political or other opinion, national or social origin, property, birth or other status.” In addition, the Court also elaborates the definition of discrimination, whereas

"...the requirements prescribed by the law to fill a particular public office does not necessarily mean in direct contradiction to the 1945 Constitution simply because (hypothetically) it contains a different moral standard from what the public understood and believed to be "evil", but the requirements determined by the law would inevitably be contradictory to the 1945 Constitution if, among other things, contain discriminatory provisions, that is, if it contains the discriminatory character of persons based on religion, race, ethnicity, language, gender, political beliefs, or other specific social status. ${ }^{28}$

${ }_{28}$ Decision 15/PUU-VI/2008, 15. 
Table 3.

International Law as a Reference in Constitutional Court Decisions

\begin{tabular}{lc}
\hline \multicolumn{1}{c}{ International Law Instrument } & $\begin{array}{c}\text { Number of } \\
\text { Citation }\end{array}$ \\
\hline International Covenant on Civil and Political Rights & 22 \\
\hline Universal Declaration on Human Rights & 13 \\
\hline International Covenant on Economic, Social and Cultural Rights & 8 \\
\hline $\begin{array}{l}\text { Convention on the Elimination of All Forms of Discrimination } \\
\text { against Women }\end{array}$ & 2 \\
\hline Convention on the Rights of the Child & 1 \\
\hline $\begin{array}{l}\text { International Convention on the Protection of the Rights of All } \\
\text { Migrant Workers and Members of their Families }\end{array}$ & 1 \\
\hline $\begin{array}{l}\text { ILO Convention concerning Labour Inspection in Industry and } \\
\text { Commerce }\end{array}$ & 2 \\
\hline UN Convention Against Corruption & 2 \\
\hline UN Convention on the Law of the Sea & 1 \\
\hline The Cairo Declaration on Human Rights in Islam & 1 \\
\hline Basic Principles of the Independence of the Judiciary & \\
\hline
\end{tabular}

Source: author

The issue of discrimination is not limited only to definitions. It is also relevant for the application of law, as demonstrated by the cases concerning equal treatment in the right to vote. The protection to the right to vote is one the most fundamental in the democratic society. Nonetheless, the 1945 Constitution does not express the right to vote in the bill of rights catalogue. In the examination of the government policy on the restriction requirements to be candidates for member of Parliament (Decision 011-017/PUU-I/2003), the Constitutional Court relates the discrimination policy to the Article 2 of UDHR and Article 25 of the ICCPR. Both provisions emphasize the importance of the protection of rights to vote rights without any discrimination. The Constitutional Court for its part held that

“...the constitutional right of citizens to vote and right to be candidate is a right guaranteed by the constitution, international law and convention, the limitation of deviations, omissions and the abolition of such rights constitutes a violation of the human rights of the citizen."29

29 Decision 011-017/PUU-1/2003, 35. 
In this reasoning, the Court did not only review the constitutionality of the policy that create discrimination to the right to vote but, at the same time, the Court held that right to vote is a constitutional right even though the constitution did not expressly mention it..$^{30}$

Other than decision by the majority opinion, the Court allows dissents opinion which incorporated in the decision. The personal views of constitutional justices as expressed in dissenting opinions also contain a number of references to international law (table 4). However, the format of the Constitutional Court's decision makes it impossible to identify the personal views of each judge. The drafter for the majority is not mentioned. As it is a common tradition in the format of the court decision in civil law countries. The main reason for this practice is to emphasize solidity and common-shared views. In fact, the publication of dissenting opinions is an unusual practice. It is far difference with the writing of court decisions on common law countries. ${ }^{31}$

Therefore, the analysis on the dissenting opinion as written by the individual constitutional justices may provide a glimpse of their views on the use of international law as a reference in the decisions of the Constitutional Court. However, there are also some shortcomings from a quantitative point of view. The large number of dissenting opinions provided by the single judge does not necessarily represent his open attitude towards making reference international human rights law. It is possible for a judge to have an open mind towards international law but rarely disagree with the majority of the judges. This study provides information that constitutional judges, in their personal views, have an open attitude towards making references to international law.

Another important question that needs to be addressed is the reason the constitutional judges use international law as a matter of consideration. What is the function of international legal references in the decision of a constitutional case?

Bisariyadi, "Hak Pilih Sebagai Hak Konstitusional: Hak Konstitusional Turunan Ataukah Hak Tersirat? [Right to Vote as Constitutional Right: A Constitutional Derivative Right or An Implied Right?]", in Al Khanif et.al eds., "Hak Asasi Manusia: Dialektika Universalisme vs Relativisme di Indonesia [Human Rights: Universalism v. Regionalism]", (Yogyakarta: LKiS, 2017), 199-220.

$3^{1}$ Michael Kirby, "Judicial Dissent - Common Law and Civil Law Tradition," Law Quarterly Review 4, http://www. hcourt.gov.au/assets/publications/speeches/former-justices/kirbyj/kirbyj_06.pdf accessed 21 April 2018. 
Table 4 .

Dissenting Opinion which made references to international law

\begin{tabular}{lc}
\hline Constitutional Justices & Number of references to IHRL \\
\hline HAS Natabaya & 2 \\
\hline Harjono & 2 \\
\hline Maruarar Siahaan & 3 \\
\hline M. Laica Marzuki & 4 \\
\hline Abdul Mukhtie Fadjar & 1 \\
\hline I Dewa Gede Palguna & 3 \\
\hline Maria Farida Indrati & 2 \\
\hline M. Arsyad Sanusi & 3 \\
\hline Hamdan Zoelva & 2 \\
\hline M. Akil Mochtar & 1 \\
\hline Aswanto & 1 \\
\hline Anwar Usman & 1 \\
\hline Patrialis Akbar & 1 \\
\hline
\end{tabular}

Source: author

\section{TYPICAL FUNCTION}

The references to international law by constitutional courts in different countries serve as an effort to protect the rights of citizens. ${ }^{32}$ Therefore, a small number of reference of international human rights law in the Constitutional Court's decision to protect the rights of citizens is not the main issues. Decisions referring to international law are not used as the main arguments in the constitutional reasoning as constructed by the Constitutional Court. This study identifies that the use of international human rights law arguments in the Constitutional Court's decision serves to (1) provide additional arguments as a support to protect the citizens' constitutional rights, and (2) to include basic rights not yet contained in the Constitution.

32 Jackson, Constitutional Engagement, 43-44; Melissa A. Waters, "Creeping Monism: The Judicial Trend Toward Interpretative Incorporation of Human RightsTreaties", Columbia Law Review, 107 (2007): 648. 


\subsection{Provide Persuasive Arguments}

The government's attitude toward the adoption of international law is also reflected in the attitude of the courts in making international law as a reference. International law is not used as the main reference or argument first proposed in the Constitutional Court's consideration as an effort to protect the rights of citizens. International law is used by the judges as an additional reference to support his arguments of reasoning.

In connection with the integration of international law with national law, David Haljan categorizes that there are two approaches in the context. ${ }^{33}$ The first is an approach based on the Martti Koskenniemi hypothesis which states that international law is used as a framework for government in issuing policies. A second approach based on Kant's thought that international law is both a legal obligation and a binding moral force.

Using the categorisation, the Constitutional Court tends to practices the approach based on the hypothesis of Koskenniemi. ${ }^{34}$ International law is used merely as a sounding board by the Constitutional Court to provide validity and legitimacy of the decisions issued. The Constitutional Court takes advantage of international law "...not as law per se but as a moment of sober second thought instead". 35 It is also agreed by Justice I Dewa Gede Palguna who argues that the Court reference to international law “... merely as an additional tool to help ascertain the Court in interpreting the Constitution which will help it to build a comprehensive consideration...". ${ }^{6}$

One example to this is when the Constitutional Court gives an interpretation of discriminatory treatment. Article 28I (2) of the 1945 Constitution states, "Every person shall have the right to be free from discriminatory treatment on any basis...". In giving the interpretation of the phrase "on any basis", the Constitutional Court refers to Article 2 of the

\footnotetext{
David Haljan, Separating Powers: International Law Before National Courts (The Hague: TMC Asser Press, 2013 ), 289.

Martti Koskenniemi, From Apology to Utopia, (Cambridge: Cambridge University Press, 2005), 474-475.

Haljan, Separating Powers.

I Dewa Gede Palguna, "The Influence of International Law in the Indonesian Constitutional Court Decision" (Paper (unpublished) presented for General Lecture, The Hague University of Applied Science, The Hague, 24 October 2017).
} 
ICCPR. The provisions of the Convention provide that the discriminatory is a different treatment on the grounds "...race, colour, sex, language, religion, political or other opinion, national or social origin, property, birth or other status."

In a case of a policy review of differences in requirements for an incumbent to run for second term, the plaintiff argued that a difference in treatment for an incumbent running in another area with an incumbent running in the same area is a discrimination. The Constitutional Court concludes that there is no discriminatory treatment in the policy. The Court suggests that

“...Article 7 paragraph (2) letter p and Article 70 paragraph (3) of Law 10/2016 does not contain discriminatory treatment because it treats differently to different things. According to the Court, the definition of discrimination is also in line with the notion of discrimination in the International Covenant on Civil and Political Rights (ICCPR)..."37

The use of the ICCPR argument in its decision is merely use as a supporting argument for the definition of discriminatory treatment.

A different nuance of the use of international law also feels very strong in the consideration of the decision of the policy of applying the retroactive principle in the Bali Bombing case..$^{8}$ The case was decided on a split chamber of 5 to 4 . Both camps, the majority and the dissents, use international law as a reference. The majority cites international legal instruments which emphasize that non-retroactive principles should not be violated, including Article 11 (2) of UDHR; Article 7 European Convention for the Protection of Human Rights and Fundamental Freedoms; Article 4 of the ICCPR; Article 9 of the American Convention on Human Rights; and Articles 22 and 23 of the Rome Statute of the International Criminal Court. ${ }^{39}$ Whereas the dissents, the instruments of international law are used as the proposition

\footnotetext{
Decision 55/PUU-XIV/2016, 67.

Decision 013/PUU-1/2003.

Decision 013/PUU-1/2003, 39-41.
} 
that the non-retroactive principle can be set aside as long as it is limited in a particular situation. ${ }^{\circ}$

\subsection{Adding New Constitutional Rights}

The second function of the use of international law in the decision is to add the fundamental rights provided in the international treaties as a constitutional right. In practice, the addition of the right to be constitutionally protected through judicial decisions is a practice that has been widely encountered. The concept of derivative constitutional rights ${ }^{41}$ and implied rights $^{42}$ provide theoretical basis for the possibility of the court to give a certain rights a status of a constitutionally protected rights.

There are three rights that are not expressly mentioned in the Constitution, but in accordance to the Court's interpretation in the decision, these rights have the status of constitutional rights: the right to water, the right to vote, and the right to presumption of innocence. The interpretation of these rights as a constitutional right pertains to the existence of those rights guaranteed in international conventions.

In the case of the Water Resources Law (Law No. 7 of 2004), ${ }^{43}$ the Court held,

“...the constitutional basis of water regulation is Article 33 paragraph (3) of the 1945 Constitution and Article $28 \mathrm{H}$ of the 1945 Constitution which provides the basis for the recognition of the right to water as part of the right to live a prosperous and spiritual life which means to be a content of human rights". ${ }^{44}$

In other words, the Constitutional Court provides an interpretation that the right to water is a part of the citizens' constitutional rights set forth in Article $28 \mathrm{H}$, the right to live prosperous, physically and mentally. Before

\footnotetext{
Decision 013/PUU-1/2003, 65-71.

${ }_{41}$ Robert Alexy, A Theory of Constitutional Rights (Oxford: Oxford University Press, 2010), 33-38.

42 Adam Lamparello, "Fundamental Unenumerated Rights Under the Ninth Amendment and the Privileges or Immunities Clause," Akron Law Review 49, no. 1 (2015): 181; Adrienne Stone, "The Limits Of Constitutional Text and Structure: Standards of Review and The Freedom Of Political Communication," Melbourne University Law Review 23, no. 3, (1999): 695.

43 Decision 058-059-060-063/PUU-II/2004 and 008/PUU-III/2005.

44 Decision 058-059-060-063/PUU-II/2004 and 008/PUU-III/2005, 488.
} 
coming to the conclusion, the Constitutional Court considered Article 12 (1) of the ICESCR stating “(t)he States Parties to the present Covenant recognizes the right of all to the enjoyment of the highest attainable standard of physical and mental health." The UN General Comment on the article illustrates that the right to health includes not only the right to health care but also factors that determine good health including access to safe drinking water. ${ }^{45}$

In relation to the right to vote, the Constitutional Court concludes that “... the constitutional right of citizens to vote and right to be candidate is a right guaranteed by the constitution, international law and convention..." ${ }^{46}$ In giving the interpretation that the right to vote is categorized as a constitutional right, the Constitutional Court cites Article 21 (3) UDHR and Article 25 of the ICCPR.

Meanwhile, in granting the status of constitutional rights to the right of presumption of innocence, in the review of Law on the Corruption Eradication Commission (Law No. 30 of 2002), the Constitutional Court held that

“...due process of law and presumption of innocence is a central principle of a democratic constitutional state... The principle is recognized as a fundamental human right that must be protected. Implicitly, these rights are recognized and can be constructed as part of human rights and constitutional rights guaranteed and protected by the 1945 Constitution...". ${ }^{47}$

The interpretation of the Constitutional Court is to use international legal references, namely Article 11 (1) UDHR and Article 14 (2) of the ICCPR stating "everyone charged with a penal offence has the right to be presumed innocent until proved guilty according to law in a public trial at which he has had all the guarantees necessary for his defence". ${ }^{8}$

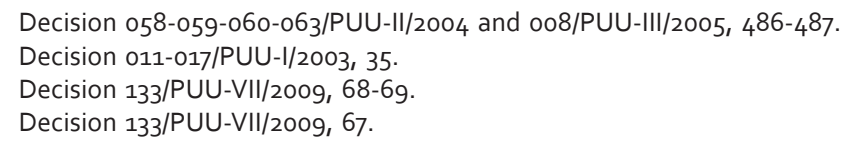




\section{CONCLUSION}

The Constitutional Court have shown an open attitude toward the use of international human rights law as reference. International human rights treaties have several functions in the constitutional review decisions of the Constitutional Court. Among them are as additional propositions in support of the reasoning constructed by the judges. In addition, international human rights law is also referred to in several decisions where the Constitutional Court upholds a basic right as a guaranteed and constitutionally protected right.

The practice of referring to international law demonstrates the Indonesian constitutional justices view towards the universal nature of fundamental rights. On the other hand, the universal nature must also be interpreted contextually with the specific culture and traditions prevailing in Indonesia. Therefore, the attitude of openness shown by the Court is still followed by prudence. Especially when accompanied by the discourse of convergence in the framework of transnational constitutionalism.

\section{BIBLIOGRAPHY}

Agusman, Damos Dumoli. "Dasar Konstitusional Perjanjian Internasional: Mengais Latar Belakang dan Dinamika Pasal 11 UUD 1945 [Constitutional Foundation on International Treaty: Taking the Background and the Dynamic of article 1 of the 1945 Constitution of the Republic of Indonesia]." Opinio Juris 4 (Januari-April 2012): 1-7.

—_—. "The Dynamic Development of Indonesia's Attitude Toward International Law." Indonesian Journal of International Law 13, No. 1 (October 2015): 1-31. Alexy, Robert. A Theory of Constitutional Rights. Oxford: Oxford University Press, 2010.

Bentele, Ursula. "Mining for Gold: The Constitutional Court of South Africa's Experience with Comparative Constitutional Law." Georgia Journal of International and Comparative Law 37, no. 2 (2009): 219-265. 
Bisariyadi, "Hak Pilih Sebagai Hak Konstitusional: Hak Konstitusional Turunan Ataukah Hak Tersirat? [Right to Vote as Constitutional Right: A Constitutional Derivative Right or An Implied Right?]", in Hak Asasi Manusia: Dialektika Universalisme vs Relativisme di Indonesia [Human Rights: Universalism v. Regionalism], edited by Al Khanif et.al. 199-220. Yogyakarta: LKiS, 2017.

Butt, Simon. "The Position of International Law Within the Indonesian Legal System." Emory International Law Review 28, no. 1 (2014): 1-28.

Chang, Wen-Chen and Jiunn-Rong Yeh. "The Use of Foreign Precedents in the Constitutional Court in Taiwan." Preliminary Report for the IACL Research Group, 2008.

Chang, Wen-Chen, "An Isolated Nation with Global-minded Citizens: Bottom-up Transnational Constitutionalism in Taiwan", National Taiwan Law Review 4, no.3 (2009): 2003-235.

Choudhry, Sujit, "Migration as a New Metaphor in Comparative Constitutional Law" in The Migration of Constitutional Idea, edited by Sujit Choudhry, 1-37. Cambridge: Cambridge University Press, 2006.

Constitutional Court Decision on Review of the Law on Electricity, No. 001-021022/PUU-I/2003 (The Constitutional Court of The Republic of Indonesia, Law 20/2002).

Constitutional Court Decision on Review of the Law on Election of Member of Parliament, No. o11-017/PUU-I/2003 (The Constitutional Court of The Republic of Indonesia, Law 12/2003).

Constitutional Court Decision on Review of the Law on Terrorist Attack on Bali Bombing, No. 013/PUU-I/2003 (The Constitutional Court of The Republic of Indonesia, Law 16/2003).

Constitutional Court Decision on Review of the Law on Water Resources, No. 058-059-060-063/PUU-II/2004 and 008/PUU-III/2005 (The Constitutional Court of The Republic of Indonesia, Law 7/2004). 
Constitutional Court Decision on Review of the Law on Election of Member of Parliament, No. 15/PUU-VI/2008 (The Constitutional Court of The Republic of Indonesia, Law 10/2008).

Constitutional Court Decision on Review of the Law on Corruption Erradication Commission, No. 133/PUU-VII/2009 (The Constitutional Court of The Republic of Indonesia, Law 30/2002).

Constitutional Court Decision on Review of the Law on ASEAN Charter, No. 33/PUU-IX/2011 (The Constitutional Court of The Republic of Indonesia, Law 38/2008).

Constitutional Court Decision on Review of the Law on Local Government, No. 55/PUU-XIV/2016 (The Constitutional Court of The Republic of Indonesia, Law 23/2014).

Ejima, Akiko."Enigmatic Attitude of the Supreme Court of Japan towards Foreign Precedents - Refusal at the Front Door and Admission at the Back Door." Meiji Law Journal 16, (2009): 19-44.

Friedman, Berry and Cheryl Saunders. "Introduction to the Symposium on Constitutional Borrowing." International Journal of Constitutional Law 1, no. 2 (2003).

Haljan, David. Separating Powers: International Law Before National Courts. The Hague: TMC Asser Press, 2013.

Jackson, Vicki C. Constitutional Engagement in A Transnational Era. Oxford University Press, 2010.

Kirby, Michael. "Judicial Dissent - Common Law and Civil Law Tradition.” Law Quarterly Review, http://www.hcourt.gov.au/assets/publications/speeches/ former-justices/ kirbyj/kirbyj_o6.pdf accessed 21 April 2018.

Kusumaatmadja, Mochtar, and Etty R Agoes. Pengantar Hukum Internasional. Bandung: Penerbit Alumni, 2003.

Koskenniemi, Martti. From Apology to Utopia. Cambridge: Cambridge University Press, 2005 . 
Lamparello, Adam. "Fundamental Unenumerated Rights Under the Ninth Amendment and the Privileges or Immunities Clause." Akron Law Review 49, no. 1 (2015): 179-206.

Lee, Suk Tae. "South Korea: Implementation and Application of Human Rights Covenants." Michigan Journal of International Law 14, (1993): 705-738.

Lovric, Daniel "A Constitution Friendly to International Law: Germany and Its Volkerrechtsfreundlichkeit." Australian Year Book of International Law 25 (2006): 75-104.

Markesinis, Basil and Jorg Fedtke. Judicial Recourse to Foreign Law. New York: Routledge-Cavendish, 2006.

Neuman, Gerald L."Human Rights and Constitutional Rights: Harmony and Dissonance." Stanford Law Review 55, No. 5 (May 2003): 1863-1900.

Osiatynski, Wiktor. "Paradoxes of Constitutional Borrowing." International Journal of Constitutional Law 1, no.2, (2003): 244-268.

Palguna, I Dewa Gede. "The Influence of International Law in the Indonesian Constitutional Court Decision." Paper (unpublished) presented for General Lecture at The Hague University of Applied Science, The Hague, 24 October 2017 .

Saunders, Cheryl. "Judicial Engagement with Comparative Law." In Comparative Constitutional Law, edited by Tom Ginsburg and Rosalind Dixon. Chetenham: Edward Elgar, 2011.

Schwartz, Herman. "The Internationalization of Constitutional Law." Human Rights Brief 10, No. 2 (2003): 10-12.

Starke, J.G. Pengantar Hukum Internasional [The Introduction of International Law], Translated by Bambang Djajaatmadja. Jakarta: Sinar Grafika, 2008.

Stone, Adrienne. "The Limits of Constitutional Text and Structure: Standards of Review and the Freedom of Political Communication." Melbourne University Law Review 23, no. 3, (1999): 668-708. 
Tsagourias, Nicholas. Transnational Constitutionalism: International and European Models. Cambridge: Cambridge University Press, 2007.

Van der Schyff, Gerhard and Anne Meuwese. "Dutch Constitutional Law in a Globalising World." Utrecht Law Review 9, no. 2 (2013).

Verdier, Pierre-Hugues, and Mila Versteeg. "International Law in National Legal Systems: An Empirical Investigation.” The American Journal of International Law 109, no. 3 (July 2015): 514-533.

Waters, Melissa A. "Creeping Monism: The Judicial Trend Toward Interpretative Incorporation of Human Rights Treaties."Columbia Law Review 107, (2007): 628-705.

Wiegand, Wolfgang. "Reception of American Law in Europe." American Journal of Comparative Law 39, no. 2, (1991): 229-248.

Wise, Edward M. “The Transplant of Legal Patterns." The American Journal of Comparative Law 38, (1990): 1-22.

Yeh, Jiunn-Rong and Wen-Chen Chang. "The Emergence of Transnational Constitutionalism: Its Features, Challenges and Solutions." Pennsylvania State International Law Review 27, no. 1, (2008): 89-124.

Zhang, Diane. "The Use and Misuse of Foreign Materials by the Indonesian Constitutional Court: A Study of Constitutional Court Decisions 2003-2008." Master Thesis, The University of Melbourne, 2010. 